\title{
THE THREAT OF GLOBAL DIMMING AND THE POLLUTION OF ATMOSPHERICH AIR CASE STUDY: GOIÂNIA-GOIÁS-BRAZIL
}

\section{A AMEACCA DO ESCURECIMENTO GLOBAL E A TUTELA DO RESSARCIMENTO PELA POLUIÇÃO DO AR ATMOSFÉRICO ESTUDO DE CASO: GOIÂNIA - GOIÁS - BRASIL}

\author{
Taís Carolina Seibt \\ MBA em Perícia, Auditoria e Gestão Ambiental \\ Gustavo Aveiro Lins \\ gu.lins@terra.com.br \\ CEDERJ/SEE-RJ/CEDAE \\ Manoel Gonçalves Rodrigues \\ manoel.rodrigues@terra.com.br \\ Observatório Urbano/UERJ/UN-Habitat \\ Josimar Ribeiro de Almeida \\ jralmeida@usp.br \\ Observatório Urbano/UERJ/UN-Habitat
}

\begin{abstract}
This work evaluates the quiet threat of the Global Blackout in the capital of Goias, Goiania, in order to evidence where level if finds such phenomenon in the city. The metodológica option occurred through a exploratoria research of data in the Climatic Station of Goiânia, qualitative and quantitative nature, and in accordance with data and maps of the radiation and solar irradiation supplied by the Ministry of Sciences and Technologies. The subject little is known in Brazil and perhaps it did not have greater seriousness in being treated by the Committee Intergovernamental de Climatic Mudanças, what it restricted of the public the access the important information on intemperies of the climate due to the high level of atmospheric pollution. In such a way, the work will be restricted to an only city since the surrounding alterations of the region, if have become each time more common and of sped up occurrence.
\end{abstract}

Key-words: Global blackout, climatic changes, ambient guardianship.

\section{RESUMO}

Este trabalho avalia a ameaça silenciosa do Escurecimento Global na capital de Goiás, Goiânia, de modo a constatar em que nível se encontra tal fenômeno na cidade. A opção metodológica ocorreu através de uma pesquisa exploratória de dados na Estação Climática de Goiânia, de natureza qualitativa e quantitativa, e de acordo com dados e mapas da radiação e irradiação solar fornecidos pelo Ministério das Ciências e Tecnologias. O tema é pouco conhecido no Brasil e talvez não houve maior seriedade em ser tratado pelo Comitê Intergovernamental de Mudanças Climáticas, o que restringiu do público o acesso a importantes informações sobre as intempéries do clima devido ao alto nível de poluição atmosférica. Desta forma, o trabalho se restringirá a um único município já que 
as alterações ambientais da região têm se tornado cada vez mais comuns e de ocorrência acelerada.

Palavras-chave: Escurecimento global, mudanças climáticas, tutela ambiental.

\section{INTRODUCTION}

Global Dimming is the reduction of solar irradiation on Earth's surface, which had begun to be observed during several decades after systematic measurements carried through in the 50's. It is believed that this fact is due to the increased amount of atmospheric aerosols, such as black carbon, caused by human action. Aerosols are considered the set of suspended particles in a gas, with high intercontinental mobility. The term refers both to the particles and to the gas in which the particles are suspended. These fragments can present varying sizes from $0,002 \mu \mathrm{m}$ to more than $100 \mu \mathrm{m}$ (a hundred micrometers). Aerosols are quickly removed from atmosphere due to occurrence of natural hydrological processes or even by simple deposition. However, there are some with high reflection capacity like sulfates, which contribute to atmosphere coolness, while others have high absorption ability, contributing to its heating. When those aerosols interact with the clouds, the process of absorption/reflection capacity starts, which cause changes in its activities as well as its duration.

The black carbon is a chemical element mainly found in aerosols, but also present in sediments and soils. This is the way the carbon produced during the incomplete combustion of fossil fuels (forming soot) or biomass is impurely formed. From 60 's to 90 's, it was believed that the effect of black carbon varied according to location, but in accordance with recent discoveries, it is known that radiation levels on the Earth's surface reduced around $4 \%$ during the period above mentioned.

This phenomenon came to be known as Global Dimming. In 1990, it was verified through initial experiences taken in Israel that Global Dimming was interfering in the hydrological cycle due to the reduction of water evaporation levels, what could be generating droughts in several regions. However, it was also observed that this phenomenon creates a reducing effect which could have partially masked the effect of greenhouse gases on global warming.

Unfortunately, the subject has been little discussed and most of the population is unaware about the phenomenon, due to the governmental caring 
about the social impact. Although there is still data in secrecy, the effects of this phenomenon have been reported with caution. Brazil, United States of America and England are the only countries which joined to study the aspects, causes and solutions for Global Dimming.

Assuming the premise that the vehicles fleet has been increasingly growing in Goiás, the State Secretariat for Environment and Water Resources has issued a new report estimating the vehicular pollutant emissions for the State and Capital. According to the inventory, the 1.696 .429 local vehicles (733.337 only in Goiânia) emit more than 300 thousand tons of pollutants gases per year in atmosphere.

Although there are more gasoline powered vehicles in Goiânia, the diesel is the fuel which most contributes to emissions. It is responsible for 64,655 of pollutants in the air of Goiânia, while the first, $30.49 \%$. Important factor considered in the inventory is that almost half of the total number of vehicles in the capital (46.74\%) has more than 11 years of use. In Goiânia, some equipment to measure the emission of gases, amount of smoke and noise were acquired and will be forwarded to the Environmental Agency, according to former Secretary of SEMARH - Secretariat for the Environment and Water Resources, José de Paula Moraes Filho.

The environmental agency, previously cited, has already three measurement stations, two in Goiânia and one in Anápolis. They work between May and October, a period of drought and when there is accumulation of residues in air. According to the Director of the Department of Environmental Surveillance of the Environment Agency (AMMA), Francisca Rossi, the device required for the measurement of the pollutants, called opacimeter, was recently acquired and soon must be in operation. According to him, every day the Agency receives reports on air pollution, either from vehicles or houses fireplaces and industries and marble industries.

With this, it is important to analyze which are the climate changes that such Greenhouse Gases have raised in the Capital, and check in which level the Global Dimming phenomenon is found.

\section{THE RISKS OF GLOBAL DIMMING IN THE CAPITAL}

The following data from 2004-2008 provided by the National Institute of 
Meteorology along with the 10ำ District of Meteorology of Goiás and Tocantins were evaluated in Goiás to check the incidence of the current phenomenon, for the following observations:

- $\quad$ Annual and monthly precipitation;

- Solar radiation;

- $\quad$ Speed of the winds;

- $\quad$ Maximum and minimum temperature.

So that it has an evaluation of the global dimming in the capital, we also need to verify the index of air quality referring to the volume of particulate material in the atmospheric air, regarding pollution. These data were provided by the Laboratory of Air Quality Monitoring of the State Secretariat for Environment and Water Resources - SEMARH/GO, that will subsequently compared with solar radiation, temperature and precipitation of the years 2004-2008.

\section{OBSERVATION OF GLOBAL DIMMING IN GOIÂNIA}

Due to the current situation in Goiânia, the following analysis considering factors like precipitation, solar radiation, maximum and minimum temperatures, population growth, vehicles fleet, urban fires and concentrations of particulate material in the last 9 (2000-2008) years can be taken, where it can be noticed:

Within the parameters of annual precipitation, it can be observed in the Chart 1 that 2001, 2004 and 2006 were the rainier years and September and October the months which were distinguished in terms of precipitations. However, the years which presented the worst index of precipitation were 2000, 2002, 2003, 2005, 2007 and 2008, being this last one the worst. Amongst these years, June, July and August were the months which index of precipitation reached 0 or almost 0.

Chart 1 - a): Precipitation in Goiânia - 2000. b): Precipitation in Goiânia - 2001. c): Precipitation in Goiânia - 2002. d): Precipitation in Goiânia - 2003. e): Precipitation in Goiânia - 2004. f): Precipitation in Goiânia - 2005. g) Precipitation in Goiânia - 2006. h): Precipitation in Goiânia - 
2007. i): Precipitation in Goiânia - 2008.

a)

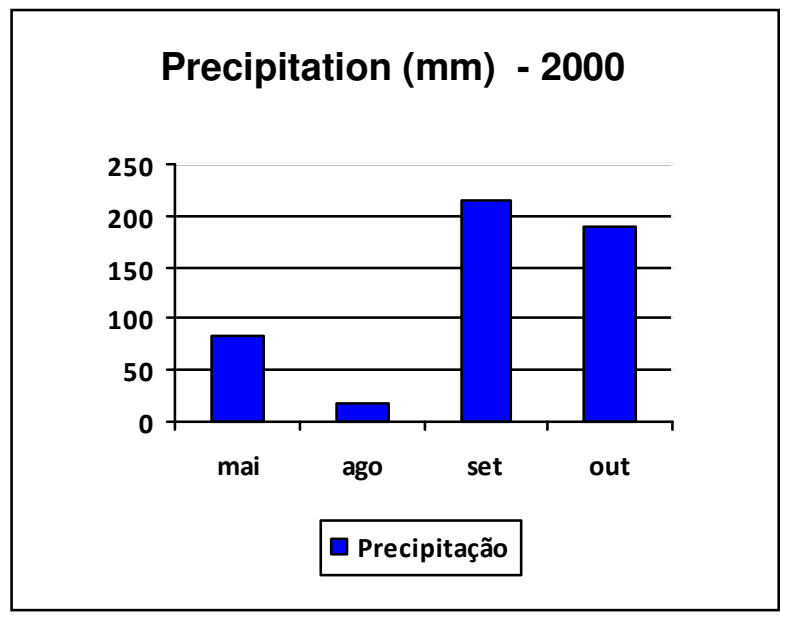

c)

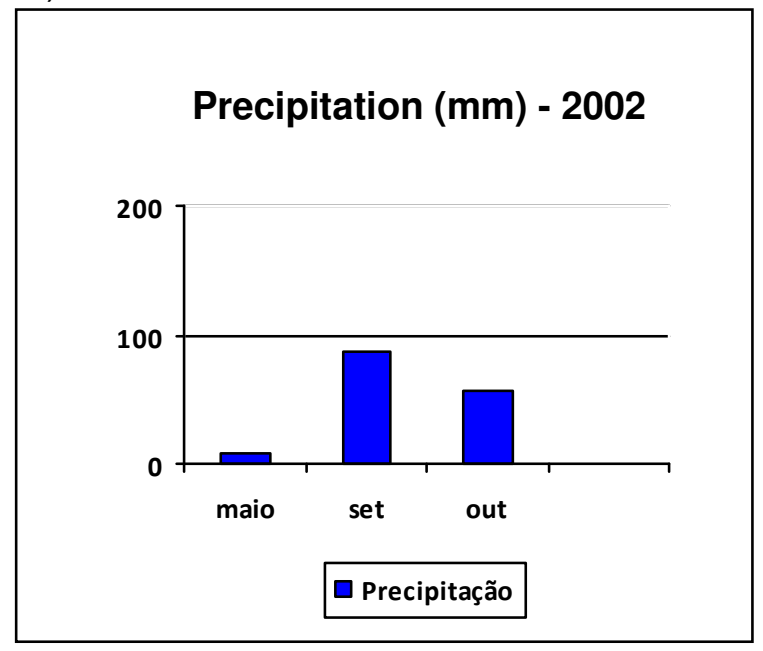

e)

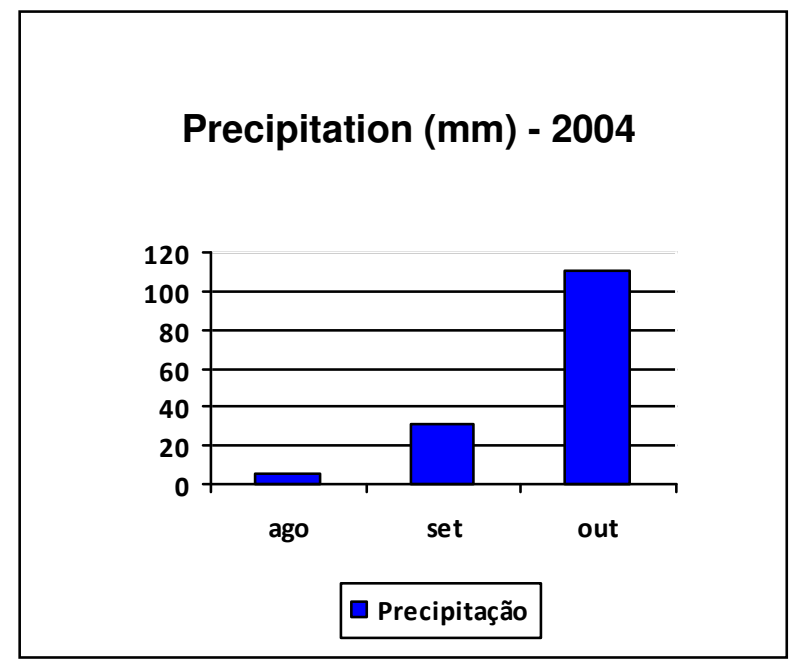

g) b)

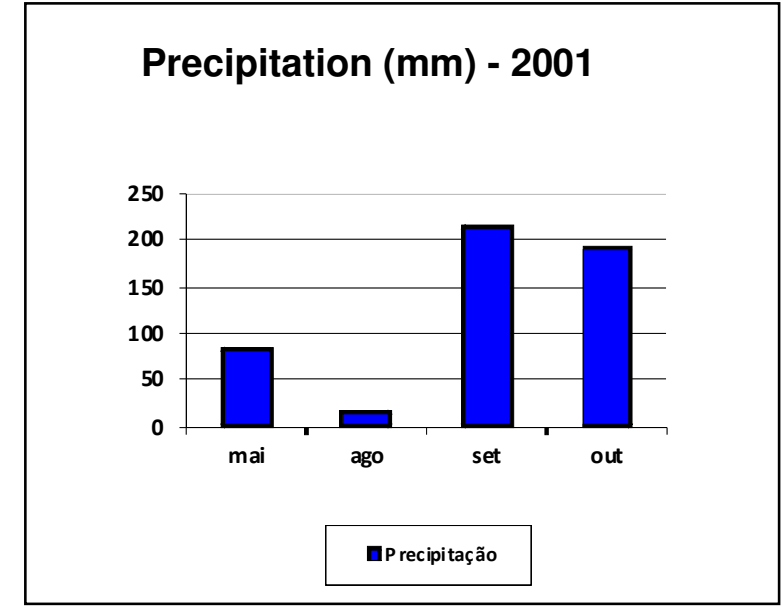

d)

\section{Precipitation (mm) - 2003}

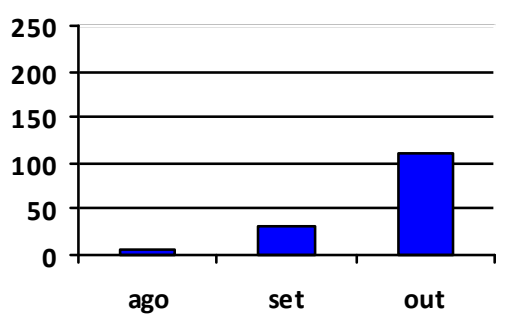

— Precipitação

f)

\section{Precipitation (mm) - 2005}

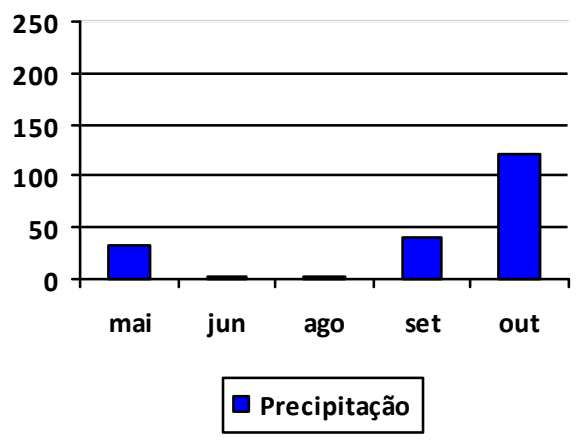



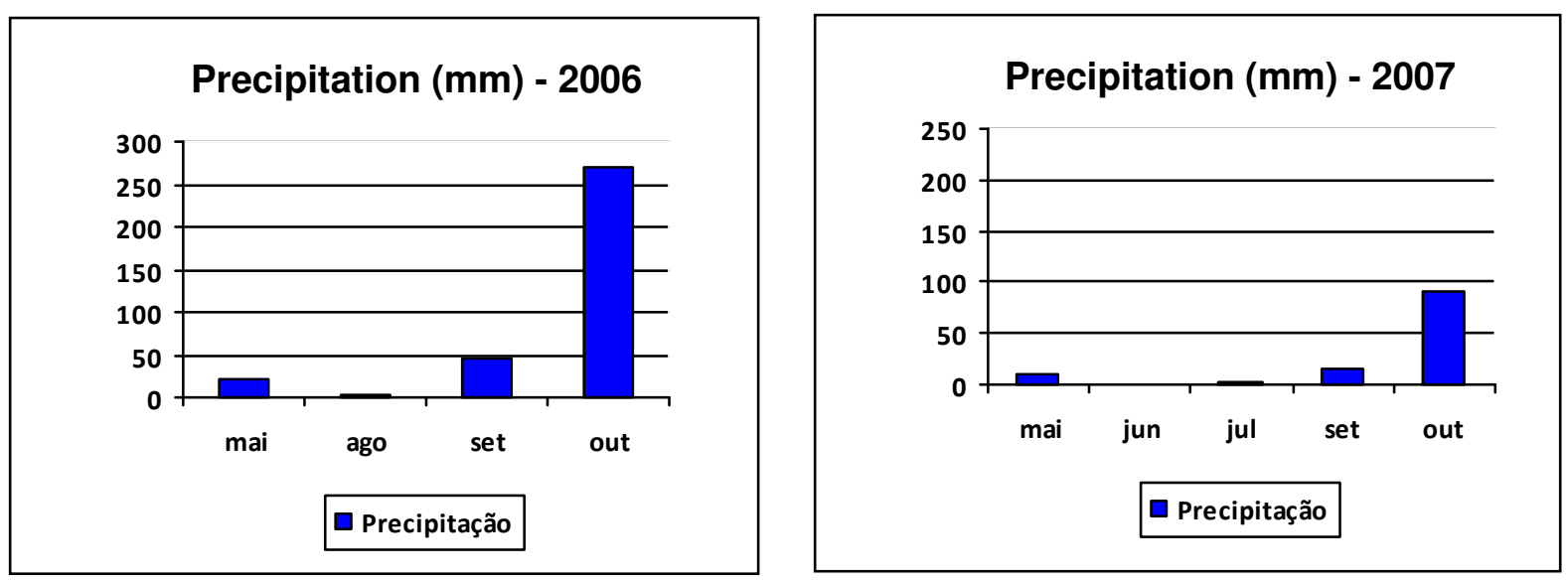

i)

\section{Precipitation (mm) - 2008}

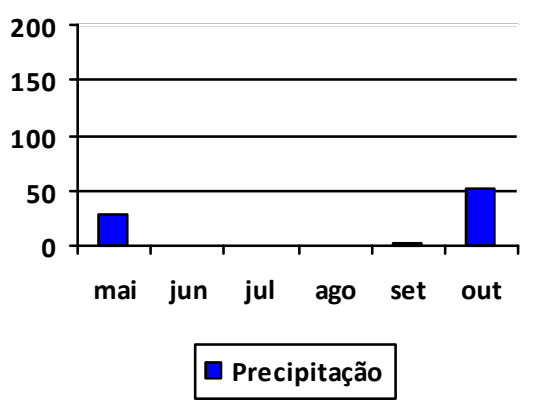

Source: FEDERAL UNIVERSITY OF GOIÁS (2008).

Regarding the solar radiation in Goiânia, it was observed that the worst rates of incidence happened in the years 2006 and 2008, with emphasis on February, March and December, in which there were low incidence on the Earth's surface.

Viewing the temperature parameters, through the Chart 2 it can be observed that the coldest years were 2000, 2001, 2002 and 2008, and the hottest ones were 2002, 2005, 2007 and 2008. Before move on, it is interesting to notice that 2002 and 2008 respectively represented cold and hot temperatures. Moreover, there was a decline of $0.8^{\circ} \mathrm{C}$ from 2007 to 2008. Although the thermal temperature has presented an increasing heat in this period, what it can be observed is that there was a certain cooling from 2007 to 2008. Would this phenomenon be linked to increasing concentrations of particulate material in the atmosphere of Goiânia?

Chart 2 - a): Minimum average temperatures in Goiânia 2000 - 2006. b) Maximum average temperatures in Goiânia 2000 - 2006. 
a)

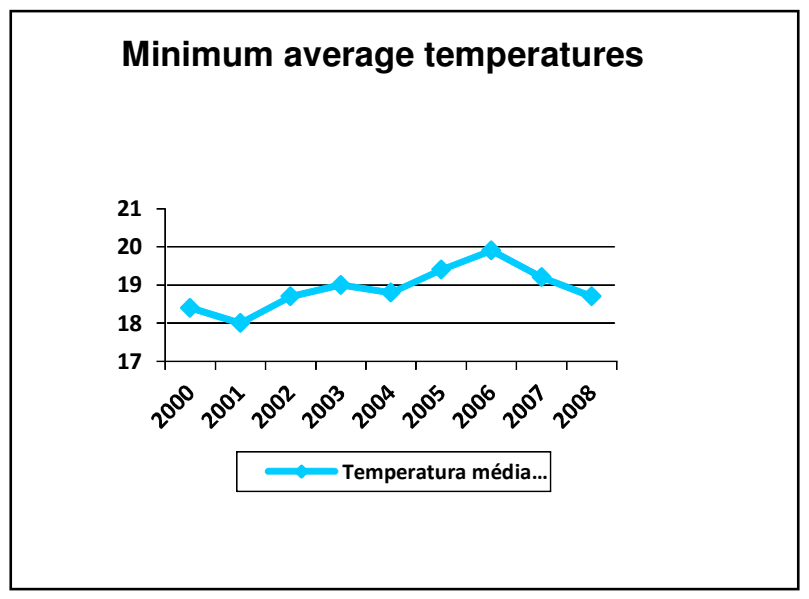

b)

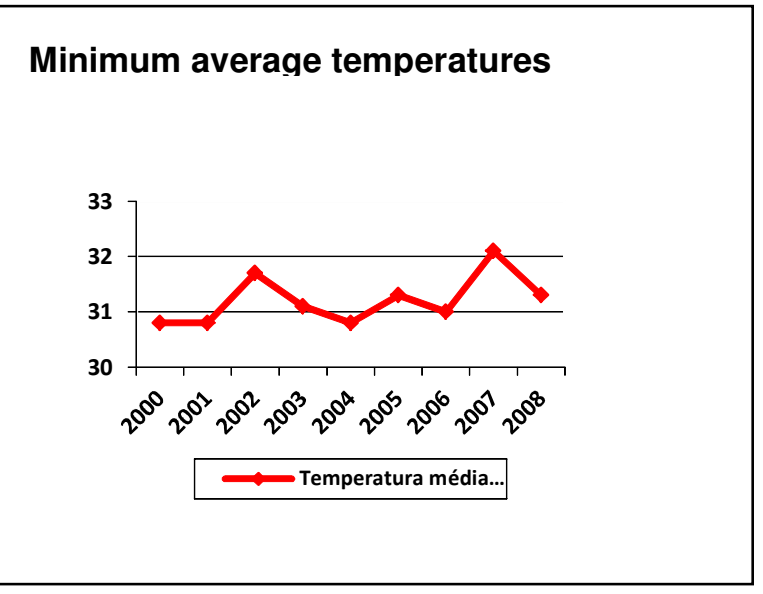

Source: INMET (2009).

In relation to population, Goiânia has had a yearly average increase of 21.500 inhabitants. Until August 2008, it had 1.265.394 inhabitants. It is estimated that until 2010 end, this population will be in the range of 1.308 .494 inhabitants.

Chart 3 - Population Growth in Goiânia 2000 - 2008.

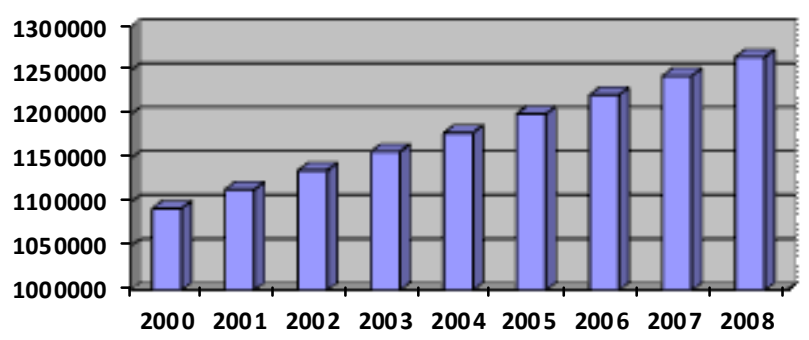

Source: SEPIN (2008).

In 2001 presents the lowest number of fires occurrences during the period as also the highest precipitation volume. However, 2003 and 2005 presented the largest number of fires, corresponding logically the same period in which the lowest precipitation indexes occurred. 2008 which represented the worst precipitation index cannot be related to the fire issue, because these data have not already been catalogued by the Fire Brigade.

Considering that the growth of vehicle fleet of Goiânia is an average of 31.115 vehicles per year, and that on 2008821.780 vehicles amongst the 
permanent and the floating were computed, it was learned that from this total gasoline has been the predominant fuel, powering about $13,15 \%$ of the total vehicles. However, it has been observed an increasing number of vehicles powered by biofuels since 2007 .

Regarding the concentration of particulate material, it can be noticed that July 2000 presented the worst indexes of concentration of particulate material in atmosphere, that reached higher places above the limits established by CONAMA, also corresponding to the period in which there was not any precipitation according to what it was showed in Chart 1a, being one of the years which obtained the lowest temperatures. When observing the year of 2002, the periods which presented the highest peaks of PM were August and September (Chart 4); August presented lesser precipitation than September, that year also presented the lowest temperatures. In 2003, (Chart 5), the highest peaks occurred in September, and observing Chart 1c, related to a period with few precipitations. In 2007 (Chart 6), the highest indexes of PM concentration occurred at the end of September and beginning of October period when the biggest precipitations occurred (Chart 1).

Chart 4-concentrations of particulate matter in Goiania-2002

\section{Concentrations of particulate matter - $2002\left(\mu \mathrm{g} / \mathrm{m}^{3}\right)$}

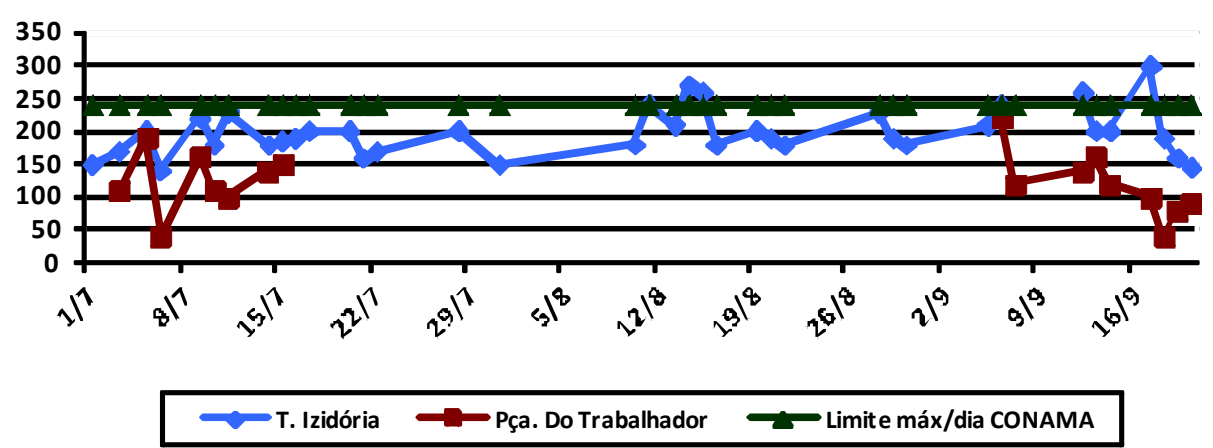

Source: SEMARH (2008).

Chart 5 - Concentrations of particulate matter in Goiania-2003. 


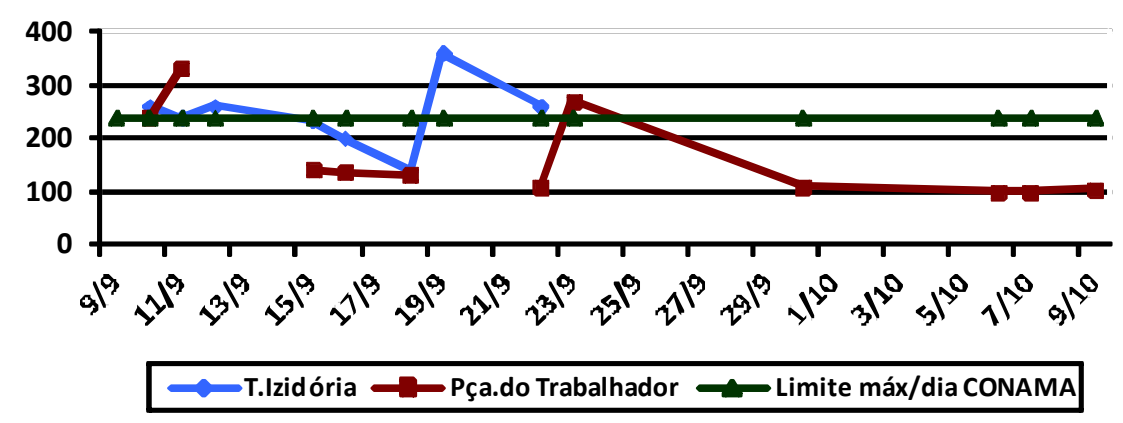

Source: SEMARH (2008).

Chart 6 - Concentrations of particulate matter in Goiania-2007.

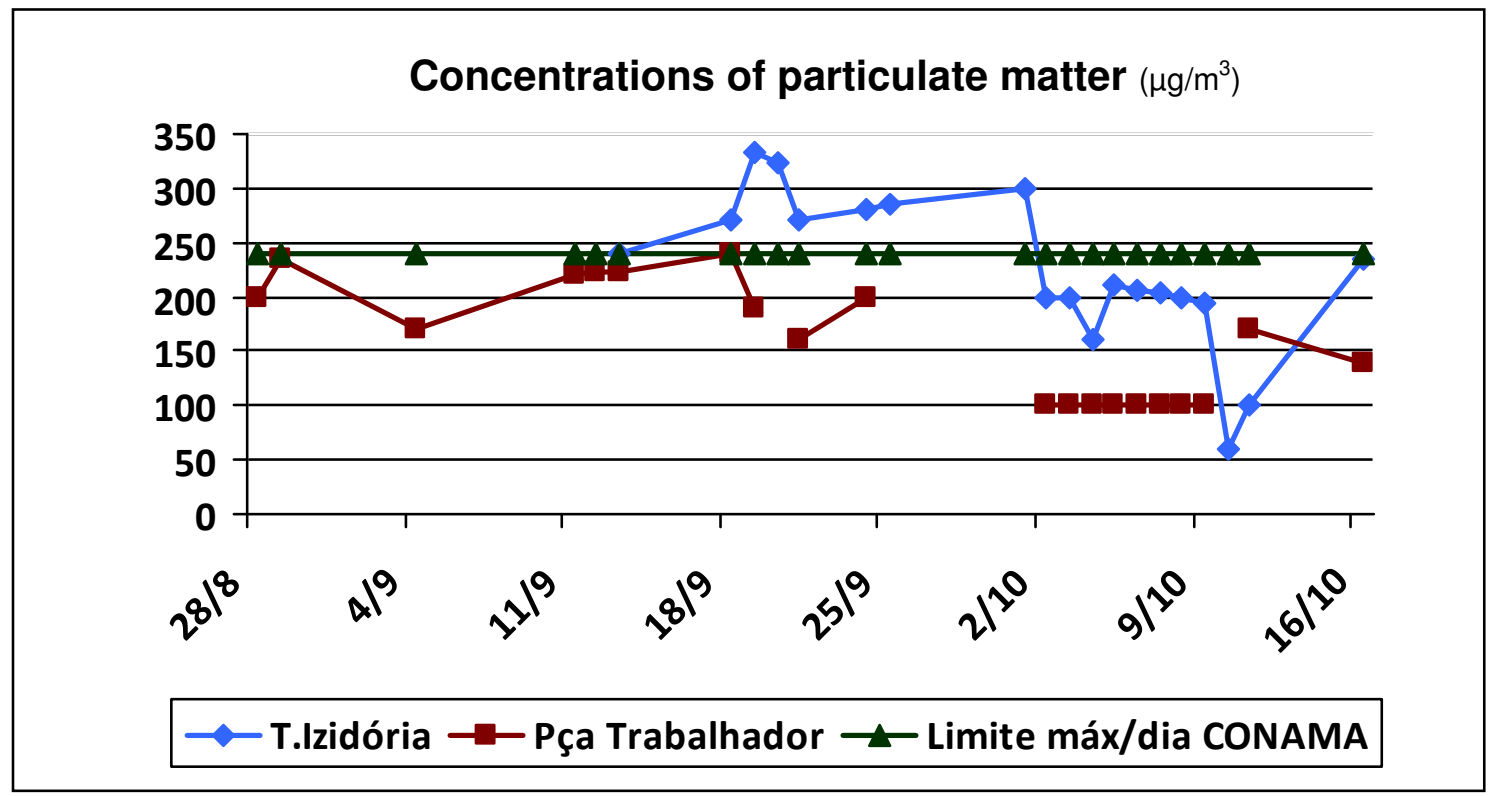

Source: SEMARH (2008).

Finally, in 2008, the peaks were not as high as in previous years (Chart 7), not exceeding the limits established by CONAMA, but reaching up its limit, what occurred in September; comparing these data with the precipitation, it can be observed that there was an incidence of rain with index of almost $0 \mathrm{~mm}^{3}$. It was also in 2008 that the lowest indexes of solar radiation occurred on Goiás' surface, taking into account its average and also that it was the year in where there was a decrease 
of $0,8^{\circ} \mathrm{C}$ in its average temperature.

Chart 7 - Concentrations of particulate matter in Goiania-2007.

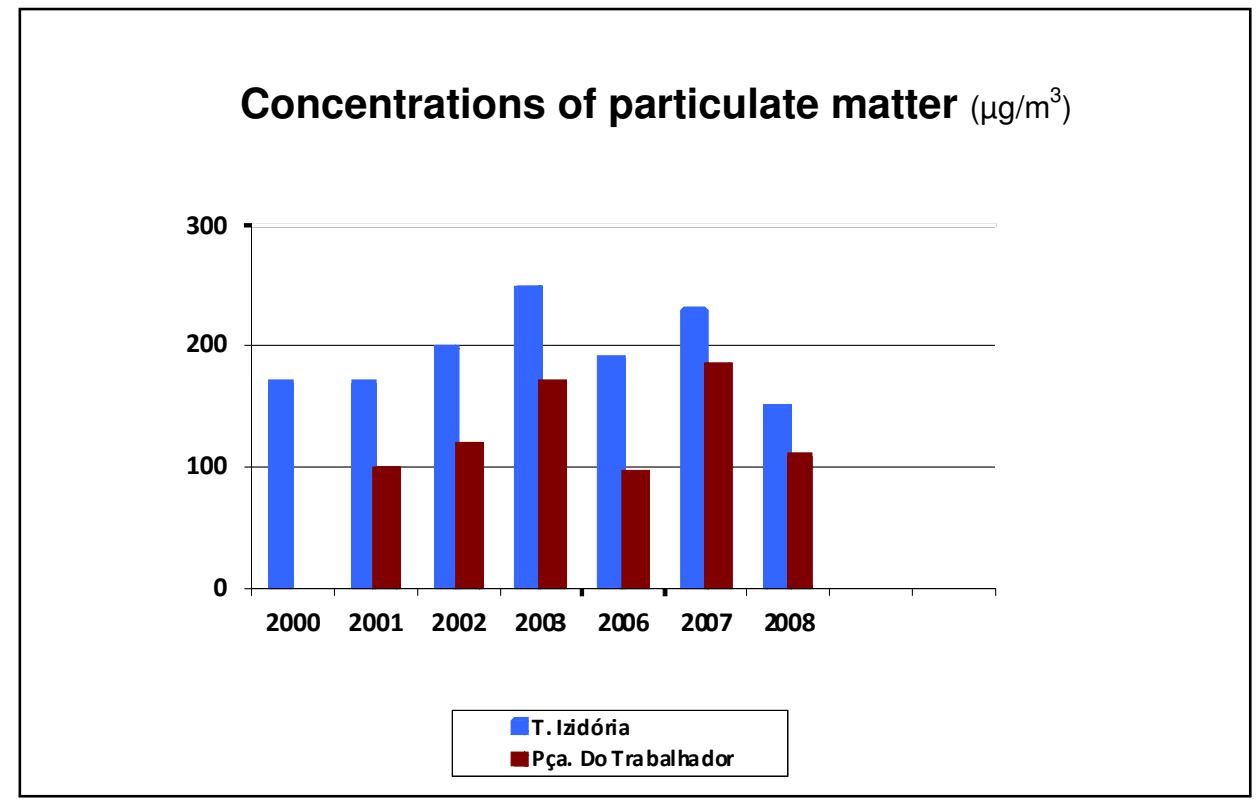

Source:SEMARH (2008).

The critical years in relation to air quality were 2002, 2003 and 2007. The sampling point that showed to be the most critical during the analysis was the Izidória Terminal.

Then, taking in account that for evidencing the Global Dimming all the data previously raised must be considered, and that in having a reduction of the average temperatures where occurred a relative increase of the concentrations of particulate material, solar radiation on surface reduction and consequently a reduction in precipitation, it can be considered that if until 2007 there were relative signals of this incidence, now in 2008, though the relative reduction of concentration of PM, we are entering in a "dark" period of the global warming.

\section{CONCLUSIONS}

It can be concluded that Goiás, as well as most part of the world, is facing weather transformation. And most of these changes can be directly related to air pollution from the automotive industry, followed by fires, industries, electronics, smokers and the others not listed in this work, like agriculture and the legal and 
illegal landfills.

Perhaps the greatest dangerous fact represented by both global warming and global dimming is not that one directly related to the rising temperatures or their own cooling, leading to humanity extinction due to its deterioration by heat or by freezing, but it can happen much earlier than these two phenomena investigated in this work. We can, long before, be suffocated" by the toxic poisoning from air pollution, by substances that can change our genetic systems, and even the extinction of one of our genres. And if this happens, the extinction of our and others species may happen even before temperatures rise or fall. In addition, there is the obstruction factor of our health, which may not withstand the intensity of global air pollution, because we depend on the air in its minimum pure way so that we can survive. So, rely exclusively on market power, even if controlled with great skill, to clean up the environment is as naive as rely solely on government intervention. On one hand, the markets need information. They will have to collect information or at least saying clearly which information they need. If polluters must pay, governments will need to measure the pollution.

Government will have to punish who cheat, as Ridley wanted the State to punish more familiar means of frauds. Surveillance, measurement and execution are functions that cannot be voluntary. They require a legal framework and the sanction of the State. When becoming the more important environmental decisions, the definitions of costs in relation to benefits are cumbersome, but it is better than nothing. It compels governments and voters to think about terms of broad orders to magnitude. Global Dimming and Planet Heating is not an exception. Those who write about climate changes in general are more interested in stopping them than to ask whether it is worthwhile to do so. Few attempts have been made to quantify the costs of preventing those phenomena.

Governments that learn to measure economic results only in GDP terms can commit terrible mistakes. The more their economies depend on the natural resources more serious will be these mistakes. The developed countries need more effective environmental statistics, but for the underdeveloped and developing countries can be a matter of life or death. In the first case, the popular interest for the environment actually has transformed the inadequacy of GDP as a measure of well-being in an important political issue. 


\section{REFERÊNCES}

SEMARRH. Secretaria do meio ambiente e dos recursos hídricos - Informativo Semarh. Disponível em: <http://www.semarh.goias.gov.br/informativos/05062006/BLITZ_PCPV.swf >. Acesso em: 05 jun. 2006.

SEMARH. Secretaria do Meio Ambiente e dos Recursos Hídricos de Goiás Programa de Controle da Poluição do Ar por Veículos em Uso. 32 p. Goiânia - GO. 2004.

SEMARH. Secretaria Estadual do Meio Ambiente e Recursos Hídricos - SEMARH. Lei estadual no 8544, de 17 de outubro de 1978. Dispõe sobre o controle da poluição do meio ambiente. Disponível em: http:/www3.agenciaambiental.go.gov.br/site/legislacao/01_legis_estad_8544.php. Acesso em: 25 nov. 2008.

SEMARH. Secretaria Estadual do Meio Ambiente e Recursos Hídricos -Relatório da Qualidade do Ar, Região de Goiânia 2001. Goiânia-GO, 2001.

SEMARH. Secretaria Estadual do Meio Ambiente e Recursos Hídricos -Relatório da Qualidade do Ar, Região de Goiânia 2002. Goiânia-GO, 2002.

SEMARH. Secretaria Estadual do Meio Ambiente e Recursos Hídricos -Relatório da Qualidade do Ar, Região de Goiânia 2003. Goiânia-GO, 2003.

SEMARH. Secretaria Estadual do Meio Ambiente e Recursos Hídricos -Relatório da Qualidade do Ar, Região de Goiânia 2006. Goiânia-GO, 2006.

SEMARH. Secretaria Estadual do Meio Ambiente e Recursos Hídricos -Relatório da Qualidade do Ar, Região de Goiânia 2007. Goiânia-GO, 2007.

SEMARH. Secretaria Estadual do Meio Ambiente e Recursos Hídricos -. Relatório da Qualidade do Ar, Região de Goiânia 2008. Goiânia-GO, 2008.

SEMARH. Secretaria Estadual do Meio Ambiente e Recursos Hídricos. Gerência de Monitoramento Ambiental - SEMARH - Relatório da Qualidade do Ar, Região de Goiânia 2000. Goiânia-GO, 2000.

SEPLAN. Secretaria do Planejamento e do Desenvolvimento do Estado de Goiás Superintendência de Pesquisa e Informação - SEPIN. Disponível em: 
<http://www.seplan.go.gov.br/sepin/>. Acesso em: 14 set. 2008.

Recebido: 15/11/2013

Aprovado: 30/11/2013 